\title{
Innovativeness and Human Capital on Performance of Small Scale Firms in Agri-Food Processing Sector in Sri Lanka
}

\author{
G. H. I. Anjalee ${ }^{1 *}$ and D. M. Semasinghe ${ }^{2}$
}

\begin{abstract}
Innovativeness is regarded as the key driver of business growth and value creation. It is also accepted that, human factor provides the competitive edge of any business industry, especially in the small-scale firms. The objectives of this study were to investigate the role of innovativeness that plays a key role in the determination of venture performance, to examine the relationship between owners' human capital and venture performance and to determine whether the relationship between innovations and venture performance is moderated by human capital factors of the firm owner. The study was mainly based on the primary data collected from 120 small scale agri-food processing firms located in Western and North-Western provinces in Sri Lanka by means of a structured questionnaire. The results of the Hierarchical Regression analysis highlighted that, innovativeness has a positive and significant relationship to the sales growth and it had no influence on employee growth. Out of the human capital variables tested, none of them were found significantly related to the sales growth of the firms. Only, the experience of owner was found to have a positive and significant impact on employee growth. Among the human capital variables concerned, only the level of education had a significant but negative effect on moderating the relationship between innovations and
\end{abstract}

${ }^{1}$ Department of Agribusiness Management, Faculty of Agriculture and Plantation Management, Wayamba University of Sri Lanka, Makandura, Gonawila (NWP)

${ }^{2}$ Faculty of Commerce and Management Studies, University of Kelaniya, Sri Lanka

*ishara.anjalee@gmail.com sales growth. Due to the positive impact of innovations on sales growth, firm owners are recommended to focus on innovations by overcoming the associated provide barriers. The policy makers are advised to provide necessary facilitations to the present and potential entrepreneurs of the sector, especially in terms of financial facilities, human resource development and technology transfer.

Keywords: Agri-food processing firms, Human capital, Innovations, Venture performance

\section{INTRODUCTION}

Innovation is the backbone of entrepreneurship which is widely recognized as a key factor in the competitiveness of nations and firms (Galia and Legros, 2004). Schumpeter (1934) argues that, innovation is an opportunity for entrepreneurial firms to gain returns through the temporary establishment of a monopoly and it is also a key source of long-term entrepreneurial success. Thus, innovation can be regarded as an important ingredient for firm performance. However, some scholars argue that innovation is an event that is fraught with a number of unwelcome elements. According to Stinchcombe (1965), firms who pursue innovative actions are particularly prone to various discouraging odds due to their newness. At the same time they are lacking internal efficiencies and sound relationships 
with different stakeholder groups (Delmar and Shane, 2004). Therefore, innovative firms are more likely to be susceptible to poor performance and failures, compared to imitative firms.

Due to the indifference nature of research findings on the relationship between innovations and venture performance, this study was designed to find out the impact of innovation on venture performance with special reference to small scale firms. This study is also expected to provide important implications for Sri Lankan entrepreneurs due to the unavailability of many studies focused on innovations and entrepreneurship in Sri Lankan context.

Entrepreneurial literature has identified number of factors that determine the success of the small firms such as individual-specific characteristics, firmspecific characteristics and industryspecific characteristics. Among those factors, individual-specific characteristics have been identified as the most prominent factor, specifically in small scale firms, where the owner of the firm plays a strategic role within the enterprise (Pennings et al., 1998). Furthermore, it is widely acknowledged that the human capital (i.e. education, start-up experience, industry experience etc.) of founders has an effect on the performance of the firm (Dimov, 2010). Human capital defined as "the knowledge, skills, competencies and attributes embodied in individuals that facilitate the creation of personal, social and economic well-being" (Organization for Economic
Co-operation and Development-OECD, 2001). The human capital attributes such as: personal characteristics, age, years of education and training, work experience of the owner of the firm, industry specific experience etc. that determine the level of success of the business. Human capital acts as a resource and it is created by changes in persons that bring about skills and capabilities that make them able to act in new ways (Coleman, 1988). Some scholars argue that, human capital and venture performance have positive relationship (Dunkelberg and Cooper, 1982) while, some others contend that there is no clear relationship between educational attainment and venture performance (Wynarczyk et al., 1993). This implies that, there are inconclusive results with regard to the relationship between human capital and venture performance.

Therefore, this study intends to fill the research gap existing between human capital and venture performance by investigating how far human capital attributes affect to the venture performance specially, within the small-scale firms with respect to a specific business sector in Sri Lanka; agri-food processing sector. Further, this study was designed to investigate the ability of human capital variables to moderate the relationship between innovativeness and venture performances.

\section{METHODOLOGY}

\section{Collection of Data}

The study was mainly based on primary data collected from 120 small scale agrifood processing firms located in Western 
and North-Western Provinces in Sri Lanka, during June - July, 2014. The sample included five firm types namely; (a) Fruit and vegetable processors (FVP), (b) Coconut \& other essential oil processors (CEO), (c) Beverage products processors (BP), (d) Dairy products processors (DP) and (e) Other processed products processors (OPP) based on the nature of its operations and output. The study employed survey method to collect the data from the respondents. Face to face interviews were conducted with firm owners/top managers in order to gather the data. Prior to the real survey, a pilot survey was carried out with a sample of fifteen small scale agri-food processing firms in order to evaluate feasibility. A list of agri-food processing firms which was obtained from the Department of Census and Statistics and respective Divisional Secretariat offices was used as the base for gathering data through Simple Random Sampling technique. Convenient Sampling techniques were also used in situations where Simple Random Sampling was not possible.

\section{Theoretical Framework}

The theoretical model included four types of variables: (a) dependent variable; firm performance, (b) independent variables; innovations and human capital; (c) control variables; firm age and firm type and (d) moderating variables; human capital characteristics (Figure 1).

Based on the model presented
above, the study specifies several
hypotheses which represent the
relationships between the established
variables. Literature in different subject
areas, such as innovation, human capital of
the founders (i.e. age, level of education and
experience), venture performance
measurements (i.e. sales growth and
employee growth) and different firm
specific characteristics (i.e. firm type, firm
age) were used to build-up these
hypotheses.

\section{Analysis of Data}

The innovativeness of each firm was measured under four types of innovations namely; product, process, management and market. A formative index was formulated to measure the innovativeness of the firms using these four types of innovations as indicators. Based on the findings of literature survey, the study has selected three variables to express owners' human capital namely; (a) age, (b) level of education and (c) years of industry experience.

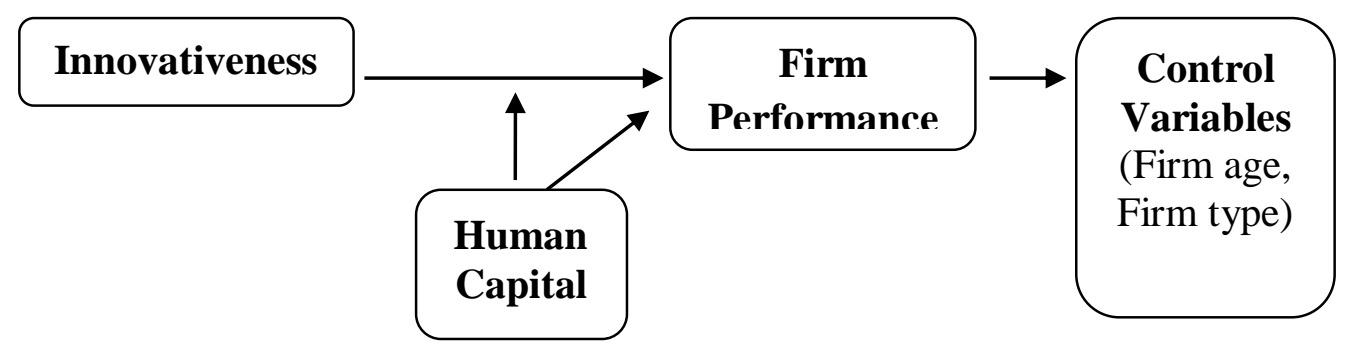

Figure 1: Theoretical model 
Further, the study used two indicators to measure the levels of venture performance of small scale agri-food processing firms namely; sales growth and employment growth. The sales and employment growth were measured as percentage growth compared to the sales and employee figures that each firm recorded five years ago. The data were analysed using both descriptive and inferential statistics for the purpose of deriving clear interpretations, understanding and arriving conclusions.

\section{Multiple Linear Regression Analysis}

For this particular study Multiple Liner Regression (MLR) analysis was carried out in order to test the relationships between identified dependent and independent variables. According to the research questions and objectives, the identified dependent variable is venture performance which is measured under two aspects; sales growth and employee growth. Therefore, two separate MLR models are fitted for two dependent variables. The set of independent variables consisted of innovation index, variables related to human capital of the owner and firm characteristics such as firm age and firm type.

The model for MLR without interaction effects is as follows.

$$
\begin{aligned}
Y=\beta_{0}+\beta_{1} I I & +\beta_{2} A g e+\beta_{3} E X P \\
& +\beta_{4} E D U+\beta_{5} F A G E \\
& +\beta_{6} F T P E+\varepsilon
\end{aligned}
$$

Where;

$\mathrm{Y} \quad$ : Firm performances (i.e.

Sales growth or Employee growth) $\begin{array}{lll}\beta_{0}-\beta_{6} & : & \text { Regression coefficients } \\ \text { II } & : & \text { Innovation Index } \\ \text { Age } & : & \text { Age of the firm } \\ \text { owner/manager } & & \end{array}$

EXP : Years of experience of firm owner/manager

EDU : Level of education firm owner/manager (Dummy variable: $1=\mathrm{Up}$ to $\mathrm{GCE} \mathrm{O} / \mathrm{L} ; 2=\mathrm{Up}$ to $\mathrm{GCE} \mathrm{A} / \mathrm{L} ; 3=$ Bachelor's degree)

FAGE : Firm age

FTPE : Firm type (Dummy

Variable : $1=$ Fruit and vegetable processors (FVP); $2=$ Coconut $\&$ other essential oils (CEO); 3 = Beverage products (BP); 4 = Dairy products (DP); 5 = Other processed products (OPP)

$\varepsilon_{\mathrm{i}} \quad$ : Error term

In this study, the MLR analysis was carried out as a Hierarchical Regression analysis in order to investigate the impact of control variables (i.e. firm age and firm type), independent variables (i.e. innovations and human capital) and the impact of interaction between innovations and human capital. Therefore, a Moderation Analysis was also carried out within the scope of MLR hierarchical analysis.

\section{Moderation Analysis}

A moderator variable changes the strength of an effect or relationship between two variables. Moderators indicate when or under what conditions a particular effect can be expected. A moderator may increase the strength of a relationship, decrease the strength of a relationship, or change the direction of a relationship. The hypotheses 
tested for three moderating variables are as follows (These hypotheses are derived from the $\mathrm{H} 3$ hypothesis given under the theoretical framework):

H3a : Age of the owner can moderate the relationship between innovations and firm performance positively

$\mathrm{H} 3 \mathrm{~b}$ : Level of education of the owner who moderate the relationship between innovations and firm performance positively

$\mathrm{H} 3 \mathrm{c}$ : Years of experience of the owner who can moderate the relationship between innovations and firm performance positively.

\section{RESULTS AND DISCUSSION}

\section{Descriptive Statistics}

The selected 120 agri-food processing firms from two provinces were categorized into five firm types, namely; (a) Fruit and vegetable processors (FVP), (b) Coconut \& other essential oils (CEO), (c) Beverage products (BP), (d) Dairy products (DP) and (e) Other processed products (OPP) based on the nature of its operations and output. Out of the total number of firms selected, $19 \%$ were belonged to the FVP firm type while $16 \%$ of the firms were belonged to CEO firm category. Majority (32\%) of the firms was under the category of OPP and $24 \%$ of them were diary food processing firms. Only $9 \%$ of the agri-food processing firms were engaged in producing beverage products (Figure 2).

Based on the data gathered, the number of innovations introduced by each firm type was analysed by considering the four types of novelty; product, process, marketing and management innovations (Figure 3).

Figure 2: Composition of firm types in the sample

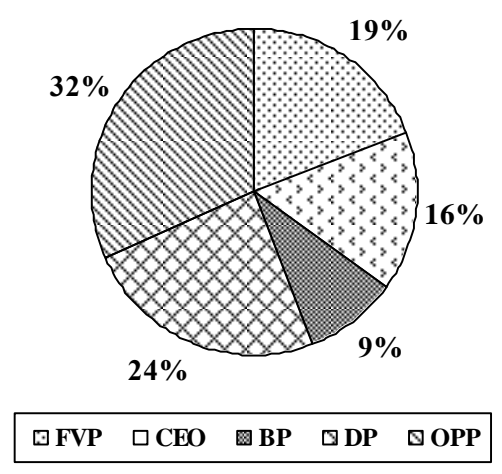

The results suggest that out of the four types of innovations, product innovations are the most common type of innovation among all five of the firm types. Firms set the first priority to introduce product innovations, regardless its firm type while, introduction of both process and marketing/ promotion innovations are also at a comparatively higher level. However, the small-scale firms in all five firm types, the introduction of management innovations are less in number compared with other three types of innovations.

\section{Outcome of the Hierarchical Regression Analysis (HRA)}

In order to measure how innovation and human capital affect on venture performance, two separate models were tested separately for sales and employee growth. 


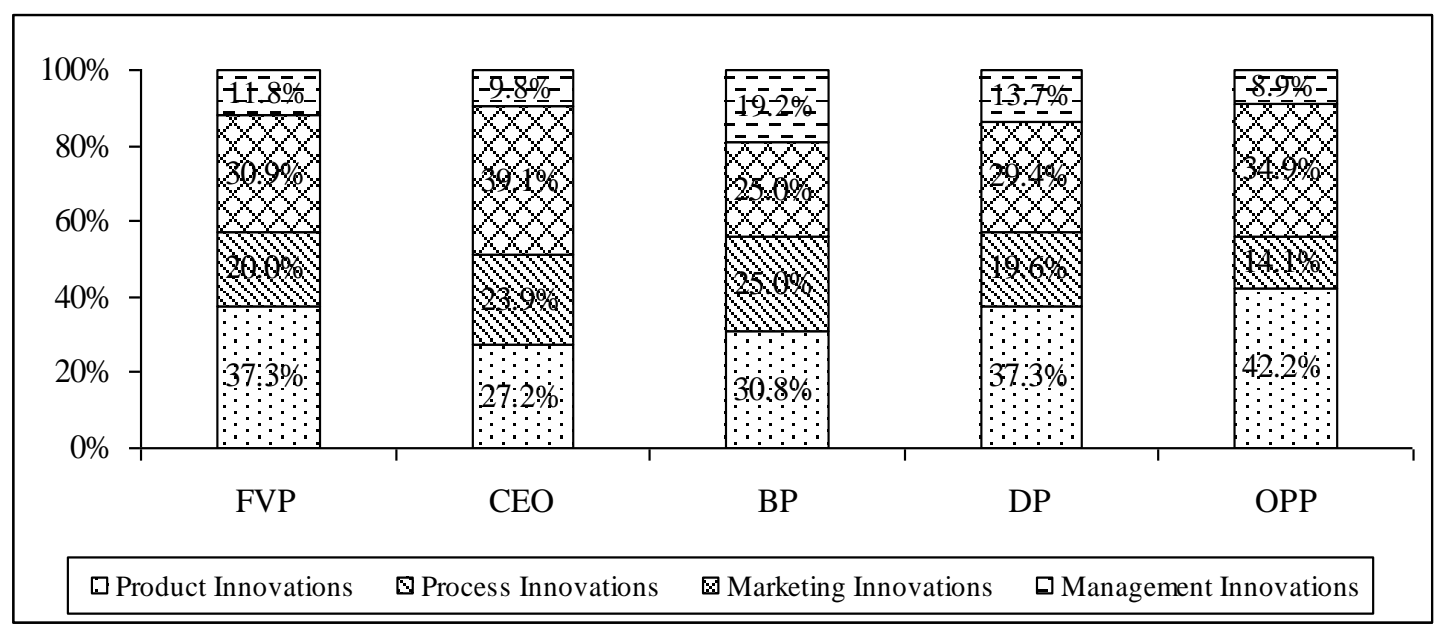

Figure 3: Number of innovations introduced by each firm type

The results of the HRA has yielded three different models where model 01 presents the base model which only reflects the effects of two control variables on dependent variable (i.e. Base model). The model two reflects the effects of main independent variables on dependent variable along with the control variables (i.e. Independent model). The third model presents the effects of both control and main independent variables and, most importantly the effects of interactions or the moderation effects which influence the relationship between independent and dependent variables (i.e. Contingency model).

Table 1, reflects the results of HRA by considering the sales growth as the dependent variable. According to the hypotheses set for the study, the first hypothesis is that, there is a positive relationship between innovations and firm performance. By observing the probability value obtained for the relationship between innovation index and sales performance for both model 02 and 03 ( $\mathrm{p}<0.05)$, it can be confirmed that null hypothesis is rejected thus, innovation has a positive and significant relationship with sales growth.

The second hypothesis for the study is that the human capital of the owner is positively related with venture performance. The term human capital was measured under three fields namely; age, education and experience of the owner. Under the second model, owners' experience was significantly related to the sales growth by rejecting the null hypothesis. Surprisingly, the negative regression coefficient reflects that the entrepreneurs with less experience achieve higher sales growths than those with higher level of industry experience. However, the results of the third model revealed that none of the human capital variables are significant at considered critical significance levels.

Considering about the third hypothesis, that human capital of the owner moderates the relationship between the 
Table 1. Results of HRA - Dependent variable: Sales Growth

\begin{tabular}{|c|c|c|c|c|c|c|}
\hline \multirow{2}{*}{ Variable } & \multicolumn{2}{|c|}{ Model 01} & \multicolumn{2}{|c|}{ Model 02} & \multicolumn{2}{|c|}{ Model 03} \\
\hline & $\beta$ & SE & $\beta$ & SE & $\beta$ & SE \\
\hline \multicolumn{7}{|c|}{ Control variables } \\
\hline Firm type & $-0.207^{* *}$ & 0.037 & $-0.202^{* *}$ & 0.038 & $-0.197^{* *}$ & 0.039 \\
\hline Firm age & 0.047 & 0.009 & 0.092 & 0.012 & 0.040 & 0.013 \\
\hline \multicolumn{7}{|c|}{ Main effect variables } \\
\hline Owners' age & & & 0.098 & 0.008 & 0.084 & 0.009 \\
\hline Education $(\mathrm{E}$ & & & -0.086 & 0.095 & -0.046 & 0.098 \\
\hline Experience $(\mathrm{I}$ & & & $-0.188^{*}$ & 0.014 & -0.118 & 0.015 \\
\hline \multicolumn{7}{|l|}{ Interaction } \\
\hline Innovation In & AGE & & & & -0.051 & 0.057 \\
\hline Innovation In & EDU & & & & $-0.170^{*}$ & 0.060 \\
\hline Innovation In & EXP & & & & -0.034 & 0.064 \\
\hline F - Statistic & \multicolumn{2}{|c|}{2.913} & \multicolumn{2}{|c|}{2.289} & \multicolumn{2}{|c|}{1.975} \\
\hline$\Delta \mathrm{F}$ & \multicolumn{2}{|c|}{2.913} & \multicolumn{2}{|c|}{1.931} & \multicolumn{2}{|c|}{1.310} \\
\hline $\mathrm{R}^{2}$ & \multicolumn{2}{|c|}{0.047} & \multicolumn{2}{|c|}{0.108} & \multicolumn{2}{|c|}{0.139} \\
\hline Adjusted $R^{2}$ & \multicolumn{2}{|c|}{$0.031^{*}$} & \multicolumn{2}{|c|}{$0.061^{* *}$} & \multicolumn{2}{|c|}{$0.069^{* *}$} \\
\hline$\Delta \mathrm{R}^{2}$ & & & \multicolumn{2}{|c|}{$0.061^{* *}$} & \multicolumn{2}{|c|}{$0.031^{* *}$} \\
\hline
\end{tabular}

Note: $\beta=$ Standard regression coefficient; $S E=$ Standard error

* - significant at 0.1 level; ** - significant at 0.05 level

innovations and human capital is related by the results shown by the model three. According to the results, the interaction between innovations and level of education is significant with a probability value of $0.073(\mathrm{p}<0.1)$ indicating that education can moderate the relationship between innovations and sales growth of the firms.

Further, out of the control variables, the probability value of firm type shows that it has a significant control over the sales growth performance of the firms in all three models $(\mathrm{p}<0.05)$. However, the relationship between sales growth and firm type is expressed as negative through the results of all three models.

Table 2 depicts the results of HRA with respect to the dependent variable of employment growth of the firms. The base model represents that out of two control variables firm type is significantly related to the employee growth of the firms $(\mathrm{p}<0.05)$. Further, this significant relationship continues throughout the three models of HRA. This indicates that firm type act as a control variable on employee growth. 
Table 2. Results of HRA - Dependent variable: Employee Growth

\begin{tabular}{|c|c|c|c|c|c|c|}
\hline \multirow{2}{*}{ Variable } & \multicolumn{2}{|c|}{ Model 01} & \multicolumn{2}{|c|}{ Model 02} & \multicolumn{2}{|c|}{ Model 03} \\
\hline & $\beta$ & $\mathrm{SE}$ & $\beta$ & SE & $\beta$ & SE \\
\hline \multicolumn{7}{|c|}{ Control variables } \\
\hline $\begin{array}{l}\text { Firm type } \\
\text { (F_TYPE) }\end{array}$ & $-0.125^{* *}$ & 0.062 & $-0.049^{* *}$ & 0.061 & $-0.061^{* *}$ & 0.065 \\
\hline $\begin{array}{l}\text { Firm age } \\
\text { (F_AGE) }\end{array}$ & 0.139 & 0.015 & -0.103 & 0.020 & -0.115 & 0.020 \\
\hline \multicolumn{7}{|c|}{ Main effect variables } \\
\hline Innovation I & & & 0.097 & 0.367 & 0.101 & 0.372 \\
\hline Owners' age & & & 0.073 & 0.014 & 0.075 & 0.014 \\
\hline Education ( $\mathrm{I}$ & & & 0.136 & 0.153 & 0.139 & 0.161 \\
\hline Experience & & & $0.364^{* *}$ & 0.023 & $0.374^{* *}$ & 0.024 \\
\hline \multicolumn{7}{|l|}{ Interaction } \\
\hline Innovation I & & & & & 0.015 & 0.093 \\
\hline Innovation I & & & & & -0.054 & 0.099 \\
\hline Innovation I & & & & & 0.024 & 0.105 \\
\hline F - Statistic & \multicolumn{2}{|l|}{2.381} & \multicolumn{2}{|c|}{3.537} & \multicolumn{2}{|c|}{2.353} \\
\hline$\Delta \mathrm{F}$ & \multicolumn{2}{|l|}{2.381} & \multicolumn{2}{|c|}{3.993} & \multicolumn{2}{|c|}{0.146} \\
\hline $\mathrm{R}^{2}$ & \multicolumn{2}{|l|}{0.039} & \multicolumn{2}{|c|}{0.158} & \multicolumn{2}{|c|}{0.161} \\
\hline Adjusted $\mathrm{R}^{2}$ & \multirow{2}{*}{\multicolumn{2}{|c|}{$0.023^{*}$}} & \multicolumn{2}{|c|}{$0.113^{* *}$} & \multicolumn{2}{|c|}{$0.093^{* *}$} \\
\hline$\Delta \mathrm{R}^{2}$ & & & \multicolumn{2}{|c|}{$0.119^{* *}$} & \multicolumn{2}{|c|}{$0.003^{* *}$} \\
\hline
\end{tabular}

Note: $\beta=$ Standard regression coefficient; $S E=$ Standard error

* - significant at 0.1 level; ** - significant at 0.05 level

Even though, the first hypothesis is that the innovativeness is positively related to the firm performance, both model two and three do not favour the hypothesis. The probability values $(p>0.05)$ indicates that there are no enough evidence to reject the null hypothesis. Therefore, it is confirmed that innovations do not have any significant influence on employee growth. The second model further records the coefficients for human capital variables. According to the hypothesis that human capital of the owner is positively related to the firm performance, the results show that only the years of experience of owner supports that hypothesis. Under both model two and three owners' experience shows a significant relationship with employee growth of the firm $(p<0.05)$. However, other two variables are not likely to have significant relationship with employee growth under both the models.

The third model, which presents the findings related to last hypothesis on moderation effect of human capital variables on the relationship of innovations and venture performance suggests that none of the interactions support to reject the null hypothesis. Therefore, it is confirmed that 
there is no moderation effect of either of human capital variables on the relationship of innovations and employee growth.

\section{CONCLUSION}

The outcome of the Hierarchical Regression Analysis highlighted that, the innovativeness is positively and significantly related to the sales performance of the firms. This result complies with most of the previous research carried out in the same field which found out that innovation can result better sales performance in firms. This positive relationship alarms the firm owners to engage more on introducing novel products, processers etc. in order to gain better results. It is suggested that, firm owners must find possible strategies to overcome the potential barriers for innovation in order to be profitable. Further, if they can go beyond imitating other firms that would be an added advantage for them to gain more sales and in turn profits.

However, the results have also suggested that, the innovations do not relate to the employee growth of the agri-food processing firms significantly. This is an understandable fact, as the firms are struggling to attract new employees and retain qualified employees within them. Regardless the type of the firm within the industry, while most of them are struggling to retain employees within them. Therefore, less or higher level of innovation within the firm has no relationship with employee growth.

The study revealed that, out of the human capital variables tested; age and level of education of the owner are not associated with sales growth as well as the employee growth of the firms significantly. It indicates that, the revenues that firm earns or number of employees they employ, does not vary with owner's education level or his/her age. It was also found that, owners' experience is positively and significantly related to the employee growth of the firms while, the experience shows no relationship with sales growth.

According to the results of the present study, the Hierarchical Regression Models suggest that, only the level of education of owner is capable of moderating the relationship between innovations and sales growth. However, the sign of regression coefficient of the variable suggests that, the level of education is moderating the relationship in a negative way. Age of the owner or the years of experience has no influence on the relationship between innovations and sales growth. The regression models also suggest that none of the considered variables are capable of moderating the relationship between innovations and employee growth. These findings would call for a further research to incorporate more human capital variables to the model in order to test the moderation effect. Since, age, education and experience do not influence the relationship between innovation and employee growth, there might be other variables that can influence such as personality characteristics of the owner.

\section{REFERENCES}

Coleman, S. J. (1988). Social Capital in the 
Creation of Human Capital. The American Journal of Sociology, 94, 95-120.

Delmar, F. and Shane, S. (2004). Legitimating first: organizing activities and the survival of new ventures. Journal of Business Venturing, 19 (3), 385-410.

Dimov, D. (2010). Nascent entrepreneurs and venture emergence: Opportunity confidence, human capital, and early planning. Journal of Management Studies, 47 (6), 1123-1153.

Dunkelberg, W.C. and A.C. Cooper. (1982) Frontiers of Entrepreneurship Research. In: Vesper, K.H., and Wellesley, M.A. (Editors), Entrepreneurial Typologies. Babson College. pp. 1-15.

Galia, F. and Legros, D. (2004). Complementarities between obstacles to innovation: evidence from France. Research Policy, 33, 1185-1199.

Organization for Economic Co-operation and Development [OECD]. (2001). The Well-being of nations: The role of human and social capital. Paris, Healey, T. \& Cote, S P 18

Pennings, J. M., Lee, K. and Witteloostuinj, A. (1998). Human capital, social capital, and firm dissolution. Academy of Management Journal, 41 (4), 425-440

Schumpeter, J. A. (1934). The Theory of Economic Development. Cambridge: MA: Harvard University Press.

Stinchcombe, A. L. (1965). Social structure and organizations. In: March, J. G.. (Editor), Handbook of organizations. Chicago, Rand McNally. pp. 142193.

Wynarczyk, P., Watson, R., Storey, D.J., Short, H. and Keasey, K. (1993). The Managerial Labour Market in Small \& Medium Sized Enterprises, Routledge, London. 